\title{
The Philosophy of Urban Reload
}

\author{
Abeer Elshater \\ Ain Shams University, \\ Cairo, Egypt \\ Abeer.elshater@eng.asu.edu.eg
}

\begin{abstract}
This manuscript introduces a new philosophy, Urban Reloading, as a compatibility effect in the great cities. The goal is to unload the metropolitan cities from carrying extra dense inhabitants and structure. It aims, firstly, to list the percentage of high structural loads, the conflict vector with surrounding conditions, and the negative influence. Secondly, it describes the injunction in making decisions related to the residents that move in and resettle outside the additional onus cities. Thirdly, it studies the new design that appropriates the city's reloaded areas and how to resettle these residents, taking into account the city formation experience with significant financial returns.

Keywords: urban design; urban infill; finding lost-space, urban renewal

eISSN 2398-4279 @ 2018. The Authors. Published for AMER ABRA cE-Bs by e-International Publishing House, Ltd., UK. This is an open-access article under the CC BY-NC-ND license (http://creativecommons.org/licenses/bync-nd/4.0/). Peer-review under responsibility of AMER (Association of Malaysian Environment-Behaviour Researchers), ABRA (Association of Behavioural Researchers on Asians) and cE-Bs (Centre for EnvironmentBehaviour Studies), Faculty of Architecture, Planning \& Surveying, Universiti Teknologi MARA, Malaysia.

DOI: https://doi.org/10.21834/ajqol.v3i9.87
\end{abstract}




\subsection{Introduction}

\subsection{Renewal By Emptying}

Today, in some great cities, the citizen suffers from an inability to live in his built environment; it seems in aspects of people and place, the morphological structure and the human behavioral settings. The city's inability to recover duties is a result of the mess providing a comfortable life, safe places, and flexible conditions. In addition, throughout time, the accumulative order of the built environment has the greatest impact in overburden on the indigenous of the mega cities. These elements of the ruling for the humans' appropriateness not only to meet the physical requirements, but also absorptive capacity loads exceed standard ratios achieved by those rates.

\subsection{The Research Problem, Hypothesis, and Slogan}

The research problem revolves around making the Great Egyptian cities get the highest value from the urban design paradigm researches. It concentrates on different architectural movements, approaches and theories, across the previous era. It, also, develops a new way to get the metropolitan cities manage their problems in addition to seeing them as livable cities. The research hypothesis expects some issues. First, if the urban designer applies the urban design principles gained from the intellectual paradigms to focus on the redistribution in the major cities, it will surely meet the requirements of livable cities. This application can be recognized at the level of interaction between people and place. Second, if the inhabitants who live in the greatest cities embrace the idea of reloading cities from the extra load, it will create preferable cities. Taking into account that the most livable cities meet the stipulations of "Quality of Life" that comes with the Post Urbanism movements.

The slogan is 'renewal by emptying'. The goal is to create a new way to retrieve the Great Egyptian cities being a livable city, not only at the level of the developed features, but also in human beings' lives. Focusing on a new technique called 'Finding Extra Load'. It will cover in the Egyptian metropolitan cities. Taking into account, the city reload is not contiguous with the principles of urban rehabilitation, restoration, and preservation. For one, it has the same concerns of the first one movements is the urban renewal, towards removing the built areas. On the other side, it moves against the purpose of conserving the buildings just for passing a decade of time. The contribution is not only dealing with the built environment, but also with people; the original inhabitant, city-visitor or worker. It, also, extends to developing unique solutions to solve the everyday problems of the informal housing sectors; in the Great Egyptian cities.

\subsection{Great Egyptian Cities Today}

Today, overcrowding and informality is a remarkable phenomenon in Egyptian cities, but is most evident in Cairo. Cairo the Capital city, geographically, located in the Greater Cairo Region. That region is home and attracts the value to almost 25 percent of all Egyptians (UNHABITAT, 2011, pp. xix, 13), (Sims, 2011).. The majority of the country's main activities huddles in the city or pass through it. The great majority of services; media outlets, hospital, 
and universities are centralized in Cairo. In addition, this centralization makes Cairo suffers from overcrowded congestion, Figure 1.

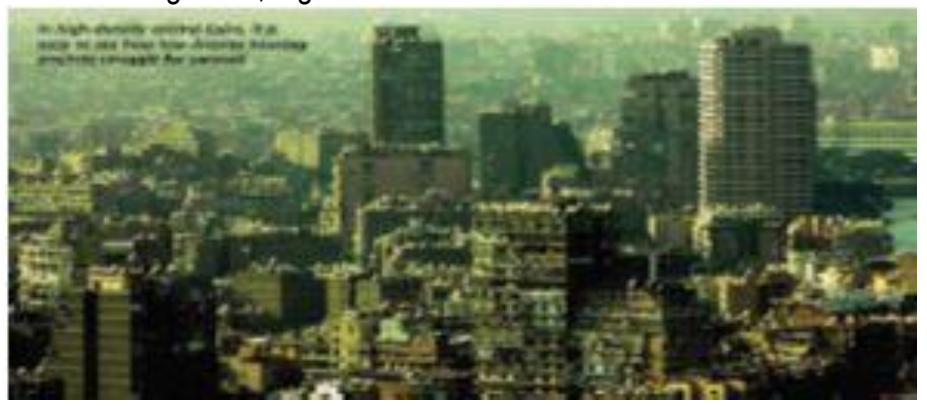

Figure 1: The urbanization in Cairo in the last few years ago, source: (UN-Habitat, 2011),

\subsection{Hidden Reload Thought In Egyptian Readings: Content Analysis}

The content analysis aims to identify the articles discuss ideas for dealing with Cairo as whole. First, a certain species in Cairo addressed as 'Cairo From Below' represents some ideas done by students and younger researchers in 2012 (Dkardo, 2013). This compilation explores some ideas concerns Cairo future as the greatest city. The research focuses on two proposals, Figure 2.

Different articles indicate to the transforming of the governmental buildings from inside the Cairo to resettle in the new towns sprawl (El Kodsi, 2005); (El Dahshan, 2013). It mentions that the benefit comes to the traffic problems and overcrowding, but it does not disclose the circumstances residents gain access to that service. In addition, the Egyptian minister of the transportation plans to reduce the private car moving inside Cairo by the end of the fourth underground metro line (Abdel- Rahman, 2012). The Cairo Governor and NGO aim to develop new lightweight design shops for vendors in the new cities in order to vacate the packed in four locations, (Raouf, 2012). From the other side, this declaration meets some obligations. Egyptian inhabitants hardly stand the thought of leaving their places. The responsible persons have anonymity about the citizen needs. Thus, the matter requires the urban designer and those who understand the cities situations to develop solutions to reach consensus among citizens.

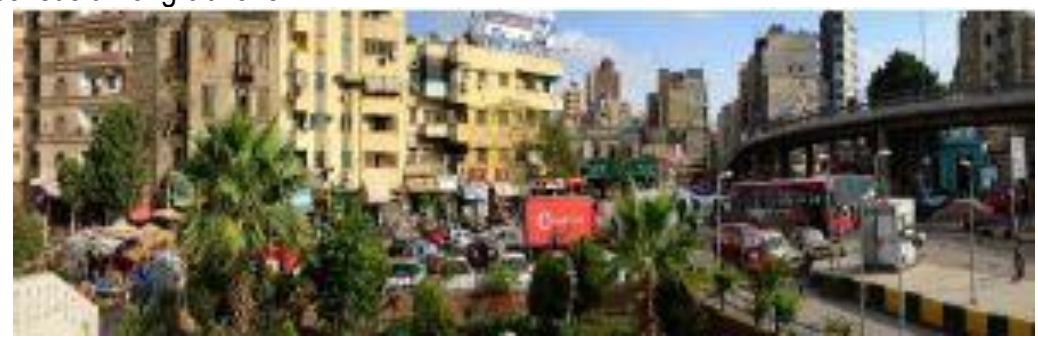

Figure 2: The chaos in the urban environment in Sayeda Zeineb, 2013

(Photography by: Ibrahim El-Sheiwi) 


\subsection{The Findings towards a New Approach}

From the field survey in Khedive's Cairo, the selected site has some constraints, potentialities, and problems (CPP). The triple-analysis CPP adopts a way to get out three findings; finding valuable assets settings as constrain, finding lost spaces (Trancik, 1986) as a potentiality and finding the extra load as a problem. Figure show some historical buildings and historical attractions as assets on the site through the two transition phase. On the other side, the field observation classifies the extra load areas as the area comes from some cases explained in (Figure 5).
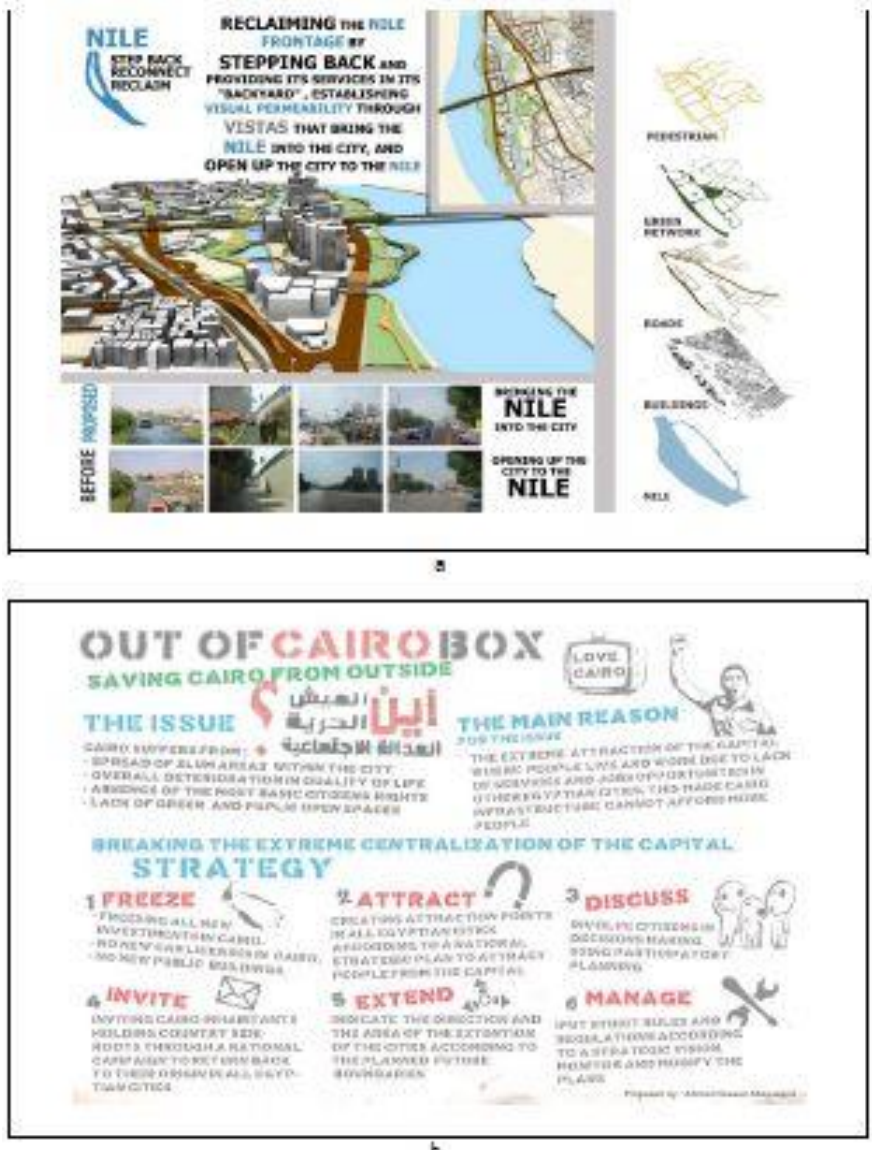

b.

Figure 3: The figures $a$ and $b$ are some proposal presented in the competition (source: (Elshater, 2013); (Abayazeed, 2012)) 


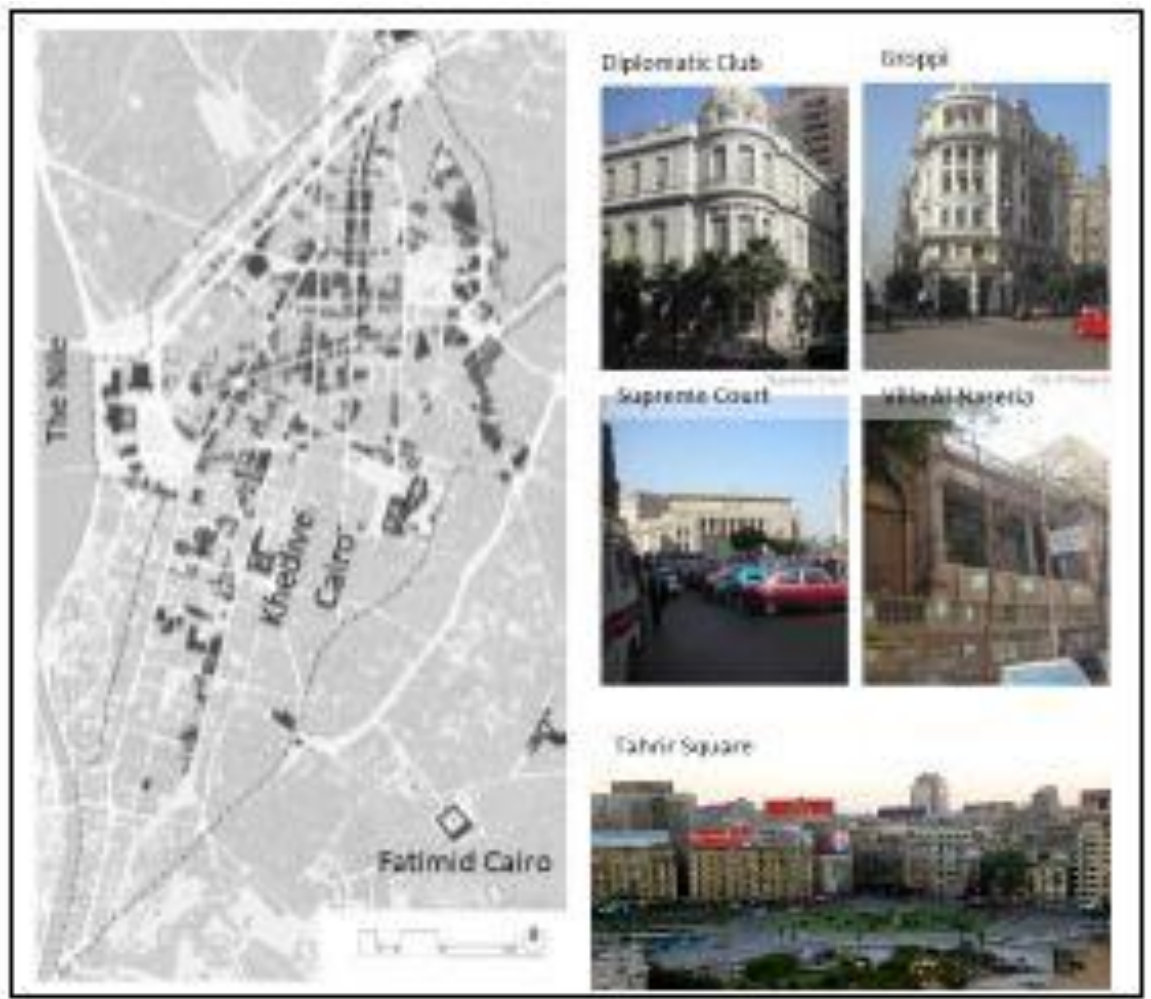

Figure 4: The selected location marked by doting line and the valuable buildings and historical appeal record in black

(Source: the author)

The current manuscript can organize them into two groups; one happens because of unplanned urbanization, the other happens because of the switched crumble sprawl. The first is a change in the city towards squatter housing (Dundar, 2001, pp. 391-401). These make burden on the city services and infrastructure. Carmona describes the following issue in Latin American cities through the own dynamic adaptation to capitalism and rapid growth (Carmona M., 1990, p. 6), (Carmona \& Tiesdell, 2007). The hidden point on both two groups is people. Public must take part in shaping the surroundings whether in renewable or/and empty. Thus, redevelop the leftover space between the districts at their boundaries by transforming them into opportunities of development. The process of finding lost-space revolves around understanding the problems that lead to creating lost spaces. These lost space are due to the disclosure requirements, the perspective of architects of the Modern Movement toward open space, and dominance of private over public interests. It sometimes 
deals with the change in functions needs that lead to a change in land use of some areas. Figure describes the typology of lost space on the site.
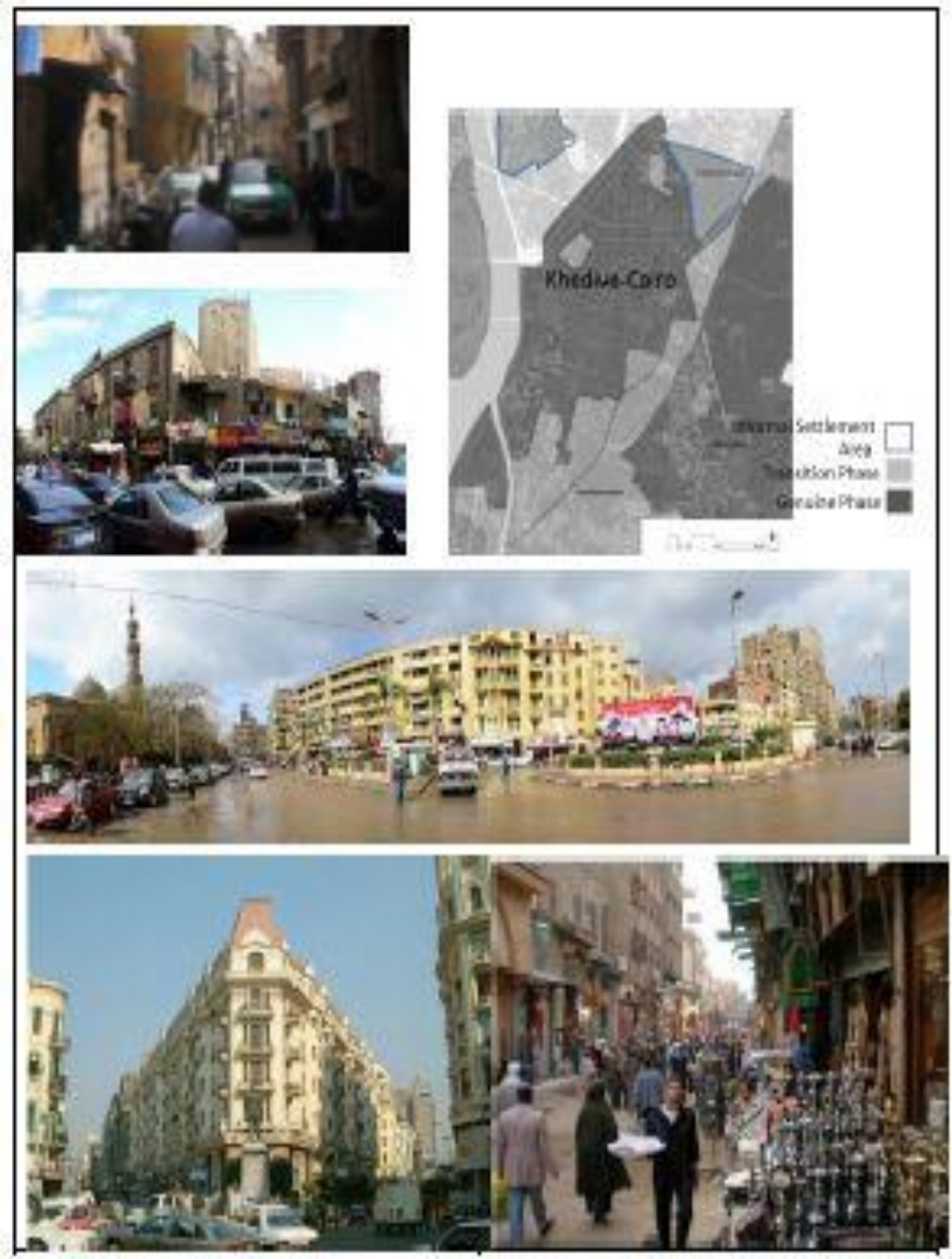

Figure 5: The Khedive Cairo

(Source: (ANA3 Office, 2010) and the photography is by El-Sheiwi, 2013) 


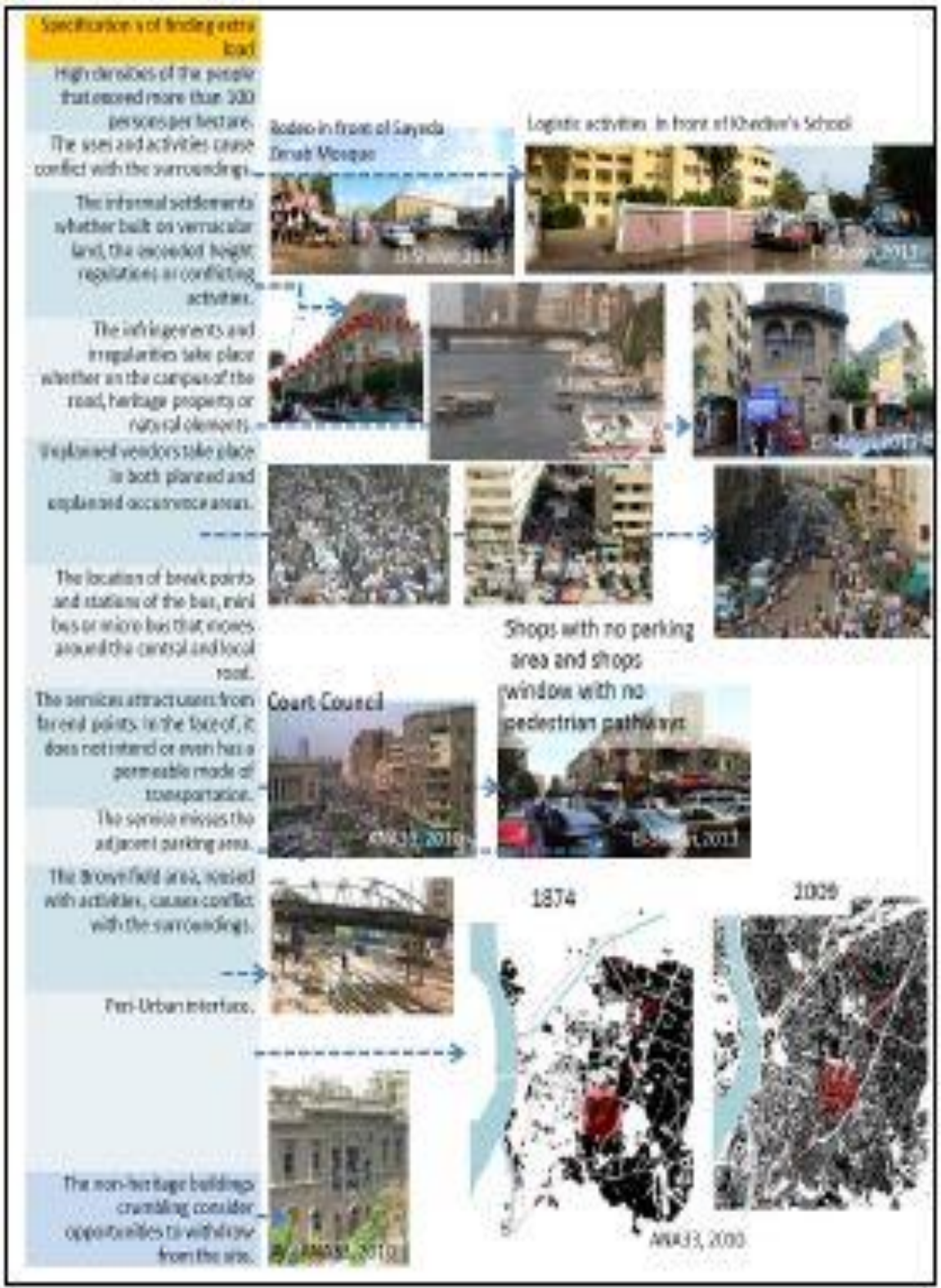

Figure 6: The classification of the extra load areas in the case study area (Source: compiled by the author based on (ANA3 Office, 2010) and photography by Elsheiwi in 2013) 


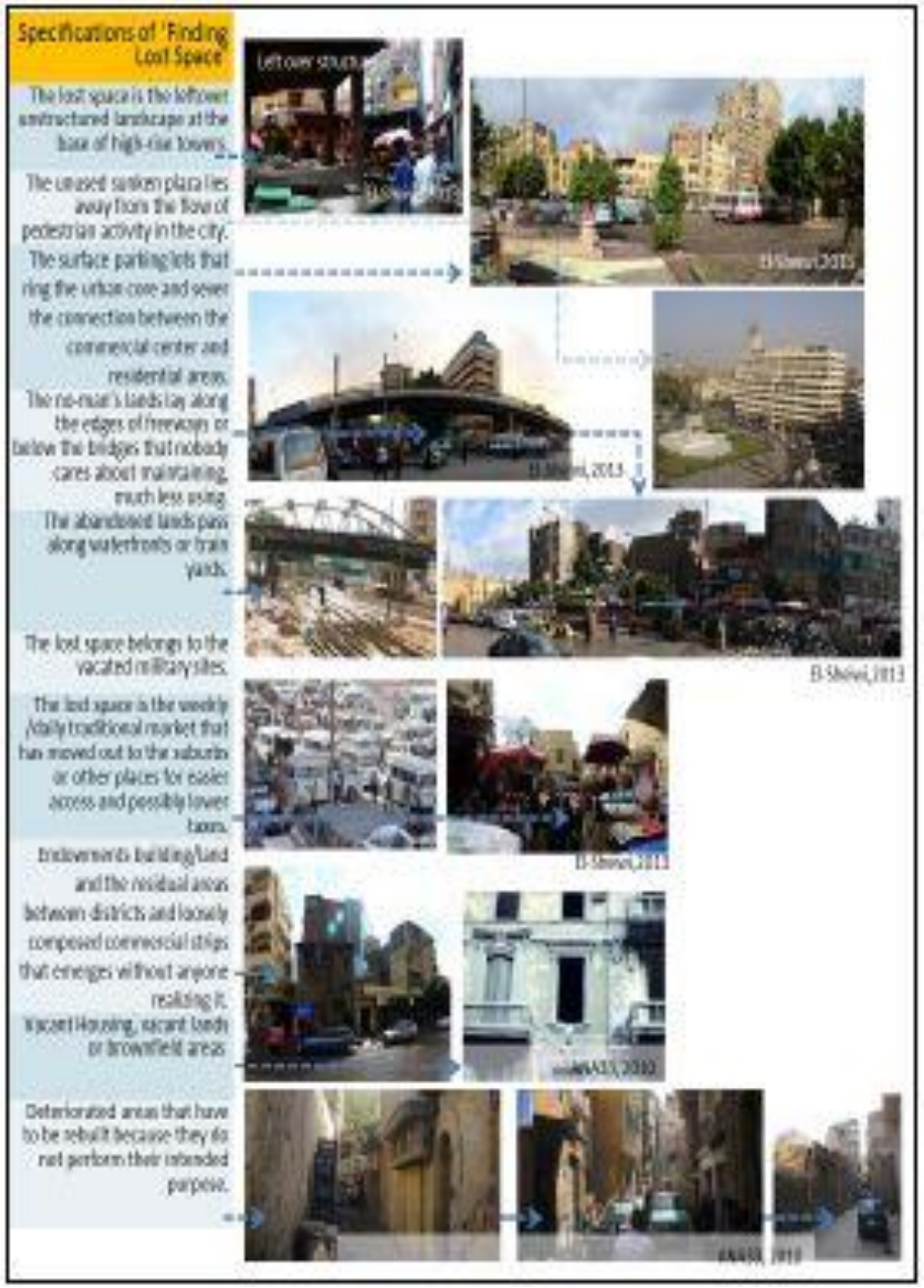

Figure 7: The classification of the lost space in the case study area

(Source: compiled by the author based on (ANA3 Office, 2010) and photography by Elsheiwi in 2013) 


\subsection{What Is Urban Reloadding Philophy?}

Some few concepts can be discussed to develop the proposed theory. First, the theory lies between two debated issues that are the most overloading area, the more inability of the residents to stay. Second, the theory considers the city gasping not only because of metropolitan transformation, but also the transformations in displacement caused by rural, day after day, to live in the city or obtain the benefits of services. Third, it believes that the low level of urbanization done by individuals and constructions is the deciding factor of the quality of services (efficiency as well as robustness) while the deterioration in the level of the daily behavior reality for residents of the yield displacement that forced in the direction of all negative, necessary facilities and quit working together.

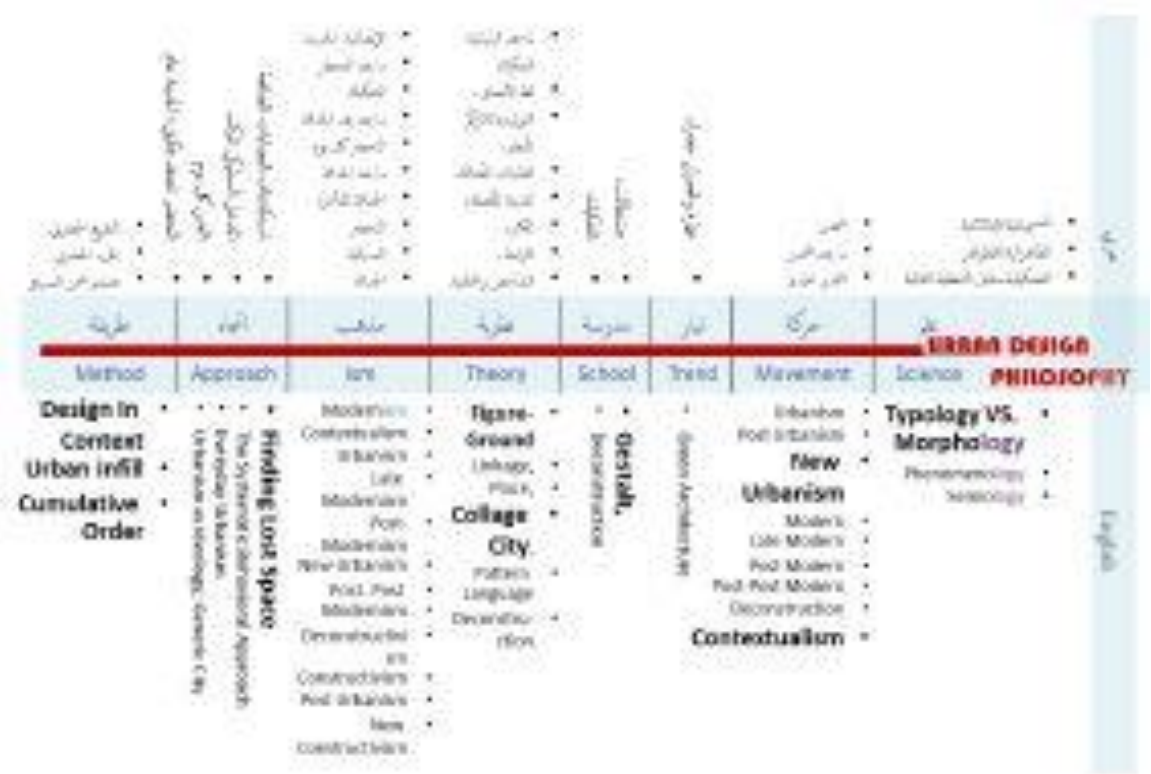

Figure 8: The urban design paradigm. The bold letters enrolled with the research problem.

(Source: the author)

Urban Reloading is a new theory, an approach and an urban design practice. The main goal is unloading the metropolitan cities from carrying extra dense inhabitants and uploaded, structural condition. The interest is in studying that cities in term of densely populated with other building structural. It aims, in the first step, starting find the percentage of high structural loaded, the conflict vector with surrounding conditions and the negative influence. It, also, helps in solving the problems of housing, business, transportation and recreation. The next step caution in taking decisions related to the inhabitants that leave and resettle outside, in other areas in the same city/town or other cities/towns. The third step focuses in considering 
a new design in a way appropriate the urban areas that have been already unloading. It, also, have an answer to how these inhabitants be resettled elsewhere with significant financial returns.

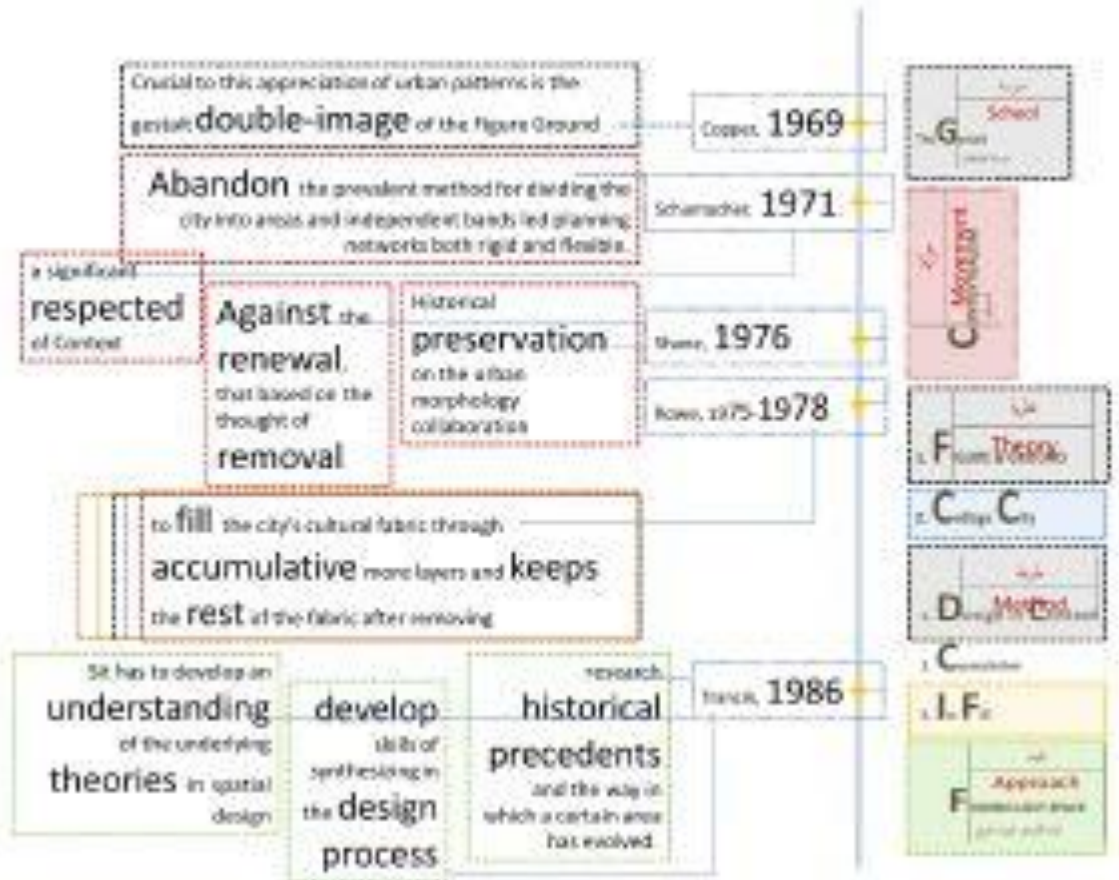

Figure 9: The significant enrollment explains the urban design paradigm (Source: the author based on (Schumaker, 1971), (Shane, 1976), (Rowe \& Koetter, 1975), (Trancik, 1986))

\subsection{Historical Enrolment}

During the middle of the last century in the period of transition from modernism to postmodernism, the western cities resemble the Egyptian cities. They summoned back to take advantage of the urban design paradigms that have not applied the thought in Egypt at all. Taking into account, the cities' experts need to redux these paradigms propose a method suit the Egyptian context. Therefore, the present work presents a new approach tangential with different movement, theories and methods in the field of urban design. The Urban Reloading quotes some principles from two movements (Contextualism and New Urbanism), finding lost space approach, three methods (Design in context, Cumulative Order and Urban Infill) in addition to theories (Collage City and Figure/Ground (Figure 9).

Pre sixties, there was a significant architectural movement aimed to revival trend takes into account the resident's social life of the city. The contemporary movement crystallized in Contextualism. The movement plan is to create morphological structure, in basis depends on 
the city synthesis characteristics. It discusses abandoning the traditional means to promote the city dividing into different areas and domains leads by the planning grids either rigid or loose (Green, 2011). That leads necessarily to control the traditional urban centers that expected the human life considered as dictated by the surrounding environmental conditions. Crucial to this appreciation of urban patterns is the gestalt double-image of the Figure/Ground (Copper, 1969, pp. 43-45). This contemporary idea was established on the urban design method that are clearly emerging in building cities with a significant respected of Context. Schumacher mentioned the built environment must match with, respond to, and reconcile surroundings (Schumaker, 1971), (Rowe and Koetter 1975, pp. 50-85), (Gaylord, 2004).

\subsection{The Theory as a Methodology}

The research proposes the theory (Figure) as a design methodology utilized within the sites of small and medium scale that varied from the city center to the neighborhood units. It appreciates some sequenced principles. First, supplement the lost spaces within the city according to the vital role. The second conveys the meaning of the urban areas by enhancing changing environments according to the citizen behavior. Third, the theory reuse all the city elements to create Semiology model within the city context. The fourth delimits by making a clear form of the negative spaces in order to highlight the main problems. Fifth, it reuses the urban design elements; groups of buildings, urban space and urban corridors, to restore the principles of good city form. Thus, the principles require finding out the missing roles of urban design elements, discarding outdated ideas and offering alternative ideas. These are to design places for recreation, satisfaction, and finding out the current trends towards fostering contemporary urban design theories.

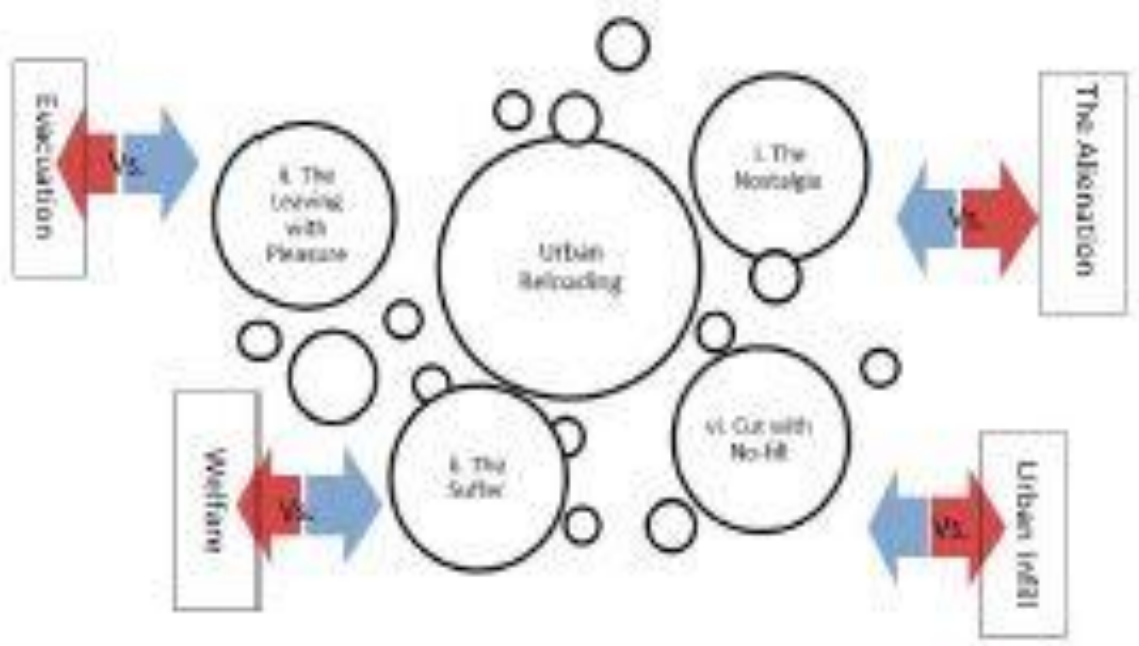

Figure10: The four factors of the proposed theory

(Source: the author) 


\subsection{The Theory as a Professional Practice}

The thought of reloading can provide some trends in both levels of urban planning and urban design. The urban planning process manages plans to develop policies. The principles at that level is classified into eight principles, Table 1.

Table 1: The principles of the proposed theory

\begin{tabular}{ll}
\hline Principle & Discussions \\
\hline $1^{\text {st }}$ & $\begin{array}{l}\text { The first principle namely that the safe exit of indigenous residents in a } \\
\text { metropolitan city is the most crucial factors in the trend towards urban } \\
\text { discharging. The discharge is based on dealing with the conflict of } \\
\text { constructions with the activities in the context of the level of land use. }\end{array}$ \\
\hline 2nd & $\begin{array}{l}\text { The second principle guides planners to avoid making great cities as points } \\
\text { of attraction, crossings or transit traffic from one place to another. This may } \\
\text { build cities safe, healthy ones, and automatically reduce the glut of mobility } \\
\text { inside them. }\end{array}$ \\
\hline 3rd & $\begin{array}{l}\text { The third principle concerns the laws and regulations that govern a particular } \\
\text { place. These are forewords to perform activities of the cities greater than } \\
\text { the ability of visitors to afford. The social-cultural, economic and legislative } \\
\text { make it unattractive cities but repellent. }\end{array}$ \\
\hline $4^{\text {th }}$ & $\begin{array}{l}\text { The fourth law provides for small cities or town adjacent rooms and more } \\
\text { facilities to the great city to accommodate their homeowner to return to their } \\
\text { birthplace. These facilities are with lower cost than larger cities do. }\end{array}$ \\
\hline 5 th & $\begin{array}{l}\text { The fifth idea comes to end, for a period not less than ten years or little more, } \\
\text { development on the vacuum land in the large cities beginning from } \\
\text { government-owned until endowments and up to individual sectors. }\end{array}$ \\
\hline 6 th & $\begin{array}{l}\text { The sixth principle tries to compensate property owners either by purchase } \\
\text { other lands outside with the same market price at the time of the swap. }\end{array}$ \\
& $\begin{array}{l}\text { Otherwise the compensate property owners can be turned to low investment } \\
\text { projects with densities. This can contribute to solve the problem of } \\
\text { transportation and communication. }\end{array}$ \\
\hline 7 th & $\begin{array}{l}\text { The seventh principle concerns the effects on the land with respect to real } \\
\text { estate investing enormous benefit. The building does not exceed 20\% of the } \\
\text { land area with multi-story height, with a requirement to provide basement } \\
\text { parking and green open spaces. In addition, fostering the walking can } \\
\text { reduce the problems of pollution and climate change. }\end{array}$ \\
\hline 8th & $\begin{array}{l}\text { Finally, the eighth principle follows the codes of the doctrines of New } \\
\text { Urbanism, Post Urbanism, and Everyday Urbanism. }\end{array}$
\end{tabular}

\section{Source: the author}

The proposed theory gets being enrolled to urban design as professional training in order to get some principles. This concerns in the building blocks and urban areas. The building block appreciates four principles. First, develop typology documentation for all urban design elements as inventory of buildings crumbling, the buildings that are inconsistent with the theme and activities that aggravate the severity of problems. The second puts a way to replace all prior activities either by making compatible uses with the current theme or transforming them into public spaces; for the concept of the public realm and urban backfill. Thirdly, reload the densities to differ from 100 to 150 persons per hectare. In addition, the urban designers should expand the size of open space per capita to vary from 15-25 $\mathrm{m}^{2}$ in 
the neighborhood unit. The fourth may come to activate the paradigm such as Contextualism, Urban Infill, Accumulation Order and Patterns Language while dealing with the idea of unloading and urban refill. The metropolitan district gets some principles. The first is listing all lost spaces in the city that not used prominent gated effects or involve activities do differently with the adjacent building in the place. The second is listing all types of life to be benchmarked in public places. Third is conceiving to take advantage of those lands and the first-floor activities of the adjacent property (without affecting the whole building). This is to solve some problems such as transport, traffic parking, movement mechanism, pedestrian movement, street vendors, squares and public squares and points of convergence.

\subsection{Conclusion: Urban Reloading Philosophy}

The paper introduces a new tool to explore and analyzes the problem of Egyptian cities. The idea of reloading revolved around the dump of the accumulation of both the individuals and the physical, built elements. It focuses on the urban design paradigms dealt with the problems of extra load areas from the morphological point of view. These can be done by: Planning leadership positions at the level of city planning, innovative methods and techniques in the city plan/design, putting and activate laws and management issues. First, the enhancing working outside to reach the decentralization and making the small cities attracting and covered by services places. Conversely, it deserves to make the great cities repellent and firm against the aggression. In addition, it makes the great cities unattractive and firm against the urban sprawl in order to strengthen the global investments. Second, work on the redesign of the greatest cities considering the urban environment to achieve livability for residents and visitors alike. Third, the regulatory framework does not tolerate infringing on the territory of the State. It provides an integrated community support for those who want to leave the city and make a strategy for damages based on a large metropolitan investment. Prospectively, the new coined terms; extra loading, urban reloading and Reload-ism will need particular future research projects. These tests whether over the present case study or elsewhere in the level of application. In addition, the current study should prepare socio-cultural studies to look for innovative solutions, which enable stopping the internal migration bleeding between provinces. On the other side, this follows how residents' nostalgia can play a role in the proposed theory.

\section{References}

UN-HABITAT-United Nations Human Settlements Programme. (2011). Cities \& Citizens series: Bridging the Urban Divide: Cairo a City in Transition. Cairo: The American University in Cairo \& Un-Habitat.

Abayazeed, A. H. (2012, December 24). Cairo from Below. Retrieved from facebook: https://www.facebook.com/\#!/photo.php?fbid=285669128202840\&set=a.285667248203028.46849.105693006200 454\&type=1\&theater

Abdel- Rahman, S. (2012, August 24). www.akhbarak.net. Retrieved from www.akhbarak.net: http://www.elbalad.com/246276 
ANA3 Office. (2010). Revitalisation of the Central Zone of Khedive's Cairo. Cairo: National Organization for Urban Harmony.

Carmona, M. (1990). Trends in Urban Restructuring in Latin Amerian. Delft: Publikatieburo Press.

Carmona, M. (2003). Public Places- Urban Spaces. New York: Architecture Press.

Carmona, M., \& Tiesdell, S. (2007). In J. Lang, Urban Design Reader. Oxford: Architectural Press.

Copper, W. (1969). Urban Design. In L. Krier, The Figure/Ground (pp. 42-52). New York: Rozzili Press.

Dkardo. (2013, January 8). Ciro from Below. Retrieved from Our Urban Futures: www.cairofrombelow.org: http://cairofrombelow.org/our-urban-futures/

Dundar, O. (2001). Models of Urban Transformation: Informal Housing in Ankara. Pergamon, Elsevier Science Ltd. El Dahshan, A. (2013, January 9). Akher Saa. Retrieved from www.dar.akhbarelyom.org

El Kodsi, H. (2005, January 9). Elshark Elaweset. Retrieved from http://www.aawsat.com/details.asp?issueno=9532\&article=293806

Elshater, A. (2013). Urban Reloading Philosophy Adequate to People-Place. Procedia - Social and Behavioural Science, pp. 526-541.

Gaylord, B. (2004, October 7). DJC.COM. Retrieved from The three C's of Urban Infill: http://www.djc.com/news/re/11161831.html

Green, W. (2011, February). Architectural Forensics. Arts Magazine. Retrieved from Assessing the seduction of design innovation on social systems.

Raouf, B. A. (2012, November 15). www.rosaelyoussef.com. Retrieved from News and Reports:: http://rosaelyoussef.com/ltem.aspx?ltemlD=4311

Rowe, C., \& Koetter. (1975). Collage City. London: MTI Press.

Schumaker, T. (1971). Contextualism. Urban Ideals and Deformations, pp. 78-86.

Shane, D. G. (1976, November). Contextualism. Architectural Design, pp. 676-679.

Sims, D. (2011). Understanding Cairo: The logic of a City Out of Control. Cairo: The American University in Cairo Press.

Trancik, R. (1986). Finding Lost Spaces: Theories of Urban Design. New York: John Willy\& Sons, Inc. 